\title{
Rising plate meters and a capacitance probe estimate the biomass of chicory and plantain monocultures with similar accuracy as for ryegrass-based pasture
}

\author{
J. HAULTAIN ${ }^{1}$, K. WIGLEY ${ }^{2}$ and J.M. LEE ${ }^{1}$ \\ ${ }^{1}$ DairyNZ Ltd., Private Bag 3221, Hamilton 3240 \\ ${ }^{2}$ Lincoln University, PO Box 85084, Lincoln 7647
}

Jamie.Haultain@dairynz.co.nz

\begin{abstract}
It is useful to gain an estimate of herbage biomass when feed budgeting. However, none of the tools that are available to estimate biomass (e.g., the rising plate meter (RPM) or capacitance probe (CP)) have been tested on popular forage herbs, such as chicory or plantain. We tested the hypothesis that RPM and CP could be used to estimate biomass of first year pure chicory and plantain swards with accuracy at least as great as for ryegrassbased pasture. In two summer experiments at different locations in the Waikato, RPM, CP and uncompressed sward height $(\mathrm{SH})$ readings were taken throughout regrowth within $0.2 \mathrm{~m}^{2}$ quadrats in chicory and plantain swards, and ryegrass-based pasture. The herbage was then cut to ground level and oven-dried to estimate biomass. Linear equations relating biomass to mean readings were generated for each method, both within each experiment and as pooled datasets. In ryegrassbased pasture, the correlation coefficients $\left(\mathrm{R}^{2}\right)$ were $0.73,0.43$ and 0.51 for RPM, CP and SH, respectively. For chicory swards, the pooled correlation coefficients $\left(\mathrm{R}^{2}\right)$ were $0.73,0.73$ and 0.81 for RPM, CP and SH, respectively, while for plantain swards the $\mathrm{R}^{2}$ were $0.70,0.59$ and 0.68 for RPM, CP and SH, respectively. This led to the conclusion that the RPM was a suitable tool for the estimation of biomass in pure chicory or plantain swards as it had similar accuracy to calibration equations for ryegrass-based pasture.

Farmers, at least in the Waikato, can estimate first year chicory or plantain biomass through the summer and autumn period using the following equations:

Chicory biomass $(\mathrm{kg} \mathrm{DM} / \mathrm{ha})=86 \times \mathrm{RPM}$ reading + 235 , or $=0.64 \times \mathrm{CP}$ reading +437 , or $=94 \times \mathrm{SH}-190$.

Plantain biomass $(\mathrm{kg} \mathrm{DM} / \mathrm{ha})=94 \times \mathrm{RPM}$ reading +455 .
\end{abstract}

Keywords: rising plate meter (RPM), capacitance probe $(\mathrm{CP})$, chicory, plantain

\section{Introduction}

Chicory (Cichorium intybus L.) and plantain (Plantago lanceolata L.) are becoming popular feed sources for New Zealand farmers during dry summer months.
Chicory and plantain have root structures that enable them to access moisture that ryegrass cannot (Rumball 1986; Stewart 1996) and, therefore, have the potential to grow large amounts of high quality feed during dry periods (Glassey et al. 2013; Minneé et al. 2013; Rollo et al. 1998). Currently, there is no suitable and quick method for farmers to estimate the herbage biomass of these two herbs. It is important to estimate herbage mass of paddocks to manage the feeding allowance of cows in a way that maximises the utilisation of feed offered by reducing wastage or over-grazing (Clark et al. 2006; Macdonald \& Penno 1998). Researchers use the cut and oven-dry method which delivers accurate results, but is labour and time intensive, making it an impractical method for most farmers.

Over the last 30 years, rising plate meters (RPM) and capacitance probes $(\mathrm{CP})$ and sward height $(\mathrm{SH})$ have been developed and used to estimate herbage biomass (L'Huillier \& Thomson 1988; Stockdale \& Kelly 1984). These instruments have been used to measure pure grass swards/mixed pastures (L'Huillier \& Thomson 1988; O'Donovan et al. 2002) and legumes (Serrano et al. 2011) with varying degrees of success (Table 1). Calibration equations for pasture mass estimations can often vary as they are affected by factors such as density of the sward, dead material (Currie et al. 1973; L'Huillier \& Thomson 1988) and herbage moisture content (Jones \& Haydock 1970; Serrano et al. 2011). Although chicory and plantain have different canopy architecture to ryegrass, there is no reason to suggest the RPM, CP and SH will not be capable of estimating chicory and plantain biomass in their first year of growth. First year crops in this study were defined as those sown in spring, with measurements taken during the first year post-sowing. Chicory plants that have been vernalised during the winter develop large, woody reproductive stems the following spring/summer (Clark et al. 1990). It is likely that these reproductive stems would greatly influence the calibration equations, depending on the proportion of leaf and stem in each sward.

We tested whether RPM, CP and uncompressed $\mathrm{SH}$ could be used to estimate biomass of first year 


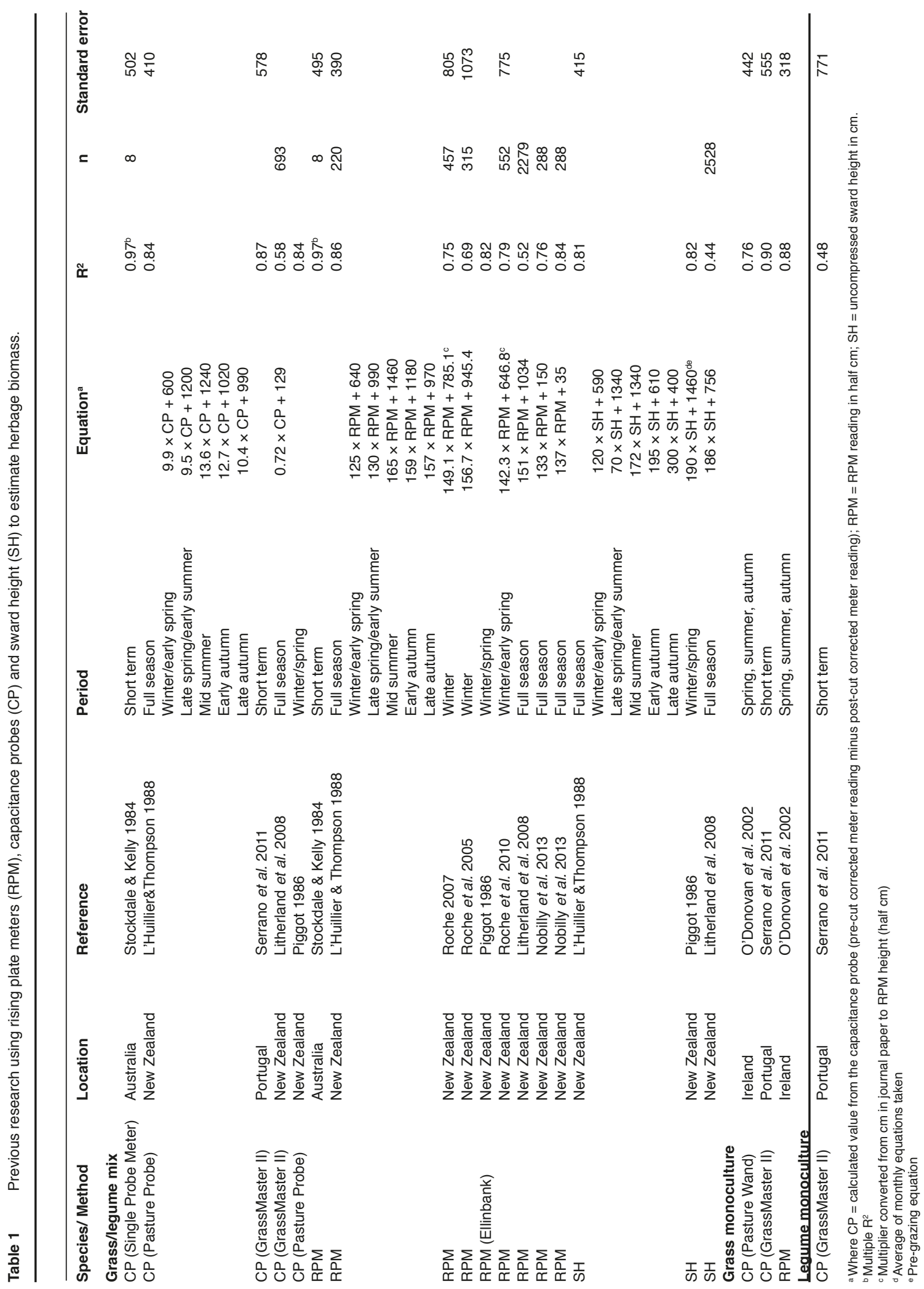


pure chicory and plantain swards at a similar level of accuracy to that obtainable by using a RPM for ryegrass-based pasture. Calibration cuts were taken in chicory and plantain swards, and in ryegrass-based pasture during two summer experiments in the Waikato.

\section{Materials and Methods}

Samples were taken from two locations in the Waikato. The first dataset was collected between January and April 2012 on a chicory sward on a commercial dairy farm in Pirongia $\left(37^{\circ} 59^{\prime} \mathrm{S}, 175^{\circ} 13^{\prime} \mathrm{E}\right)$, while the second was collected at DairyNZ's Scott farm located near Hamilton $\left(37^{\circ} 47^{\prime} \mathrm{S}, 175^{\circ} 19^{\prime} \mathrm{E}\right)$ between January and April 2013. The first dataset was used to calibrate the RPM and CP measurements against standing dry matter (DM) of an unirrigated chicory sward, while the second calibrated the RPM, CP and uncompressed SH measurements against standing DM of irrigated chicory and plantain swards, and unirrigated ryegrass-based pasture. All chicory and plantain swards were springsown (October), three months before sampling began. The ryegrass-based pastures were all well-established swards, 2 years old or older.

\section{Measurements}

Measurements for both sampling periods were taken during the summer after sowing in spring. Ten quadrat calibration cuts were taken weekly over a 3-month period that covered a range of biomass, both pre- and post-grazing. Before the quadrat $\left(0.2 \mathrm{~m}^{2}\right)$ was placed on the ground, two uncompressed SH measurements were taken using a ruler, followed by one RPM reading using a Farmworks Plate Meter $^{\mathrm{TM}}$ (Farmworks Precision; Feilding, New Zealand). The SH measurements were taken on two randomly selected leaves within the quadrat area, measuring from ground to the uppermost point of the leaf as it lay undisturbed in the sward. The RPM reading was taken before the CP unlike a previous study (L'Huillier \& Thomson 1988) as it was noted the CP would crush the chicory and plantain leaves. Pre-grazing chicory and plantain swards have a thick, tangled canopy that the CP collapsed when placed to ground level, whereas the RPM was held aloft by the canopy.

To avoid the risk of the steel quadrat interfering with the $\mathrm{CP}$ measurements, four small wooden pegs were placed at the four corners and the quadrat was removed while the $\mathrm{CP}$ measurements were taken using the GrassMaster II ${ }^{\mathrm{TM}}$ (Novel Ways Ltd, Hamilton, New Zealand). Firstly, a "clear air" reading was taken by holding the $\mathrm{CP}$ at chest height, parallel to the ground. This number was stored in the device while nine herbage readings were taken in a grid formation and averaged. All herbage within the quadrat was then cut to ground level with hand shears (chicory and plantain) or battery powered hand pieces (ryegrass-based pasture). After the herbage was cut, a further air reading and series of nine ground readings were made where the herbage had been cut. The pre- and post-air readings were automatically subtracted from the averaged preand post-cut quadrat readings respectively, to provide pre- and post-cut corrected meter readings (CMR). The post-cut CMR reading was then subtracted from the pre-cut CMR reading, effectively removing the capacitance value of the soil, which was variable due to changing soil moisture and temperature. Previous research (L'Huillier \& Thomson 1988; Serrano et al. 2011; Stockdale \& Kelly 1984) did not measure and remove the ground reading. This measurement was introduced in this study to provide a more accurate and consistent reading. Moreover, the new model of the $\mathrm{CP}$ used requires a bare soil reading before herbage measurements can begin. Herbage samples were placed on ice for transporting to the laboratory, where they were washed and oven-dried at $95^{\circ} \mathrm{C}$ for 2 days, and then weighed to estimate total DM mass.

\section{Climate}

Climate data from NIWA are presented in Table 2. The chicory and plantain swards in Hamilton also received an additional $50 \mathrm{~mm}$ of irrigation, split into two $25 \mathrm{~mm}$ applications, one in late January 2013 and the second in mid-February. The 2013 months were drier and warmer than the average while the 2012 months were wetter and cooler than average. The year 2013 was memorable for severe drought conditions.

\section{Statistical analysis}

Simple regression analyses were conducted on the data to derive an equation for each of the three data sets. The closeness of fit of the calibration equation to actual data points was calculated and used as a measure of

Table 2 Total monthly rainfall $(\mathrm{mm})$ and mean temperature $\left({ }^{\circ} \mathrm{C}\right)$ for January, February and March 2012 and 2013 , and the 30 year average (1981-2010).

\begin{tabular}{llcrc}
\hline & & $\mathbf{2 0 1 2}$ & $\mathbf{2 0 1 3}^{\mathrm{b}}$ & Average $^{\mathrm{b}}$ \\
\hline Rainfall $(\mathrm{mm})$ & January & $111.0^{\mathrm{a}}$ & 7.2 & 79.0 \\
& February & $171.2^{\mathrm{a}}$ & 20.0 & 70.0 \\
& March & $107.0^{\mathrm{a}}$ & 23.6 & 79.7 \\
& Total & 389.2 & 50.8 & 228.7 \\
Mean temperature $\left({ }^{\circ} \mathrm{C}\right)$ & January & $16.4^{\mathrm{b}}$ & 19.0 & 18.4 \\
& February & $16.9^{\mathrm{b}}$ & 18.9 & 18.8 \\
& March & $15.1^{\mathrm{b}}$ & 19.1 & 17.1 \\
& Average & $16.1^{\mathrm{c}}$ & 19.0 & 18.1 \\
\hline
\end{tabular}

a Data collected at Ngahinapouri ( $11 \mathrm{~km}$ north of Pirongia) by NIWA

${ }^{b}$ Data collected at Ruakura (5 km west of Scott Farm) by NIWA

${ }^{c}$ Average calculated using figures from the table 
accuracy (standard error) and $\mathrm{R}^{2}$ was used as a measure of correlation. Significance was tested to the $5 \%$ level $(\mathrm{P}<0.05)$.

\section{Results}

The linear calibration equations created during this experiment for chicory, plantain and ryegrass-based pasture are presented in Table 3 with all individual data points used to create each graph depicted in Figure 1. In chicory swards the $\mathrm{R}^{2}$ for all tested estimation methods were similar within each dataset, with an $\mathrm{R}^{2}$ of 0.79 0.81 obtained for all three methods in Hamilton, while in Pirongia the $\mathrm{R}^{2}$ ranged from 0.63 to 0.65 for the RPM and CP. This resulted in an $\mathrm{R}^{2}$ of 0.73 for both the RPM and $\mathrm{CP}$ when both datasets were pooled. In the plantain sward in Hamilton, the $\mathrm{R}^{2}$ ranged from 0.70 (RPM) to $0.59(\mathrm{CP})$, while in ryegrass-based pasture the $\mathrm{R}^{2}$ ranged from $0.73(\mathrm{RPM})$ to $0.43(\mathrm{CP})$.

\section{Discussion}

Data from the current study support the hypothesis that the biomass of chicory and plantain can be estimated with tools that are already used on New Zealand farms to estimate pasture mass. In New Zealand, the RPM is an accepted method of yield estimation for pasture (L'Huillier \& Thomson 1988). For yield estimation methods to be considered acceptable for first year chicory or plantain swards, the accuracy of these methods must be similar to, or greater than that for ryegrass-based pasture.

When data from the chicory swards at both sites were pooled, the $\mathrm{R}^{2}$ values for the RPM and CP were 0.73 , which was the same as the value for the ryegrass based pasture. This indicates that both methods were acceptable. Interestingly, the $\mathrm{R}^{2}$ of the Pirongia dataset collected on a commercial dairy farm was lower than that collected from the experimental sward on the DairyNZ research farm $(0.63-0.65$ vs 0.79 , respectively). Plant density in pure chicory swards can vary dramatically, with some areas containing high plant numbers and other areas much lower numbers. This may indicate that there is greater variability in crops on commercial dairy farms than in research crops which are managed much more intensively. Conversely, the plant density of the experimental sward may have declined less over time, reducing the variability in the dataset. Unfortunately, the plant densities of both swards were measured only once during the measurement period, so it is not possible to draw any conclusions regarding the source of variability. The plant density of the commercial farm sward was $103 \pm 9$ plants $/ \mathrm{m}^{2}$ when measured in early January while the plant density of the research sward was $120 \pm 35$ plants $/ \mathrm{m}^{2}$ in mid-April. This provides some indication of the swards in which our equations may be relevant.

Table 3 Calibration equations and accuracy of regression analysis for chicory, plantain and ryegrass-based pasture.

\begin{tabular}{|c|c|c|c|c|c|c|c|}
\hline Species/Method ${ }^{a}$ & Location & $\mathrm{n}$ & $\begin{array}{c}\text { Summer/Autumn } \\
\text { Period }\end{array}$ & Equation ${ }^{\mathrm{b}}$ & $\mathbf{R}^{2}$ & SD & Significance $^{c}$ \\
\hline \multicolumn{8}{|l|}{ Chicory } \\
\hline $\mathrm{CP}$ & Hamilton & 134 & 2013 & $y=0.74 \times C P+364$ & 0.79 & 551 & $* \star *$ \\
\hline $\mathrm{CP}$ & Pirongia & 85 & 2012 & $y=0.59 \times C P+419$ & 0.65 & 637 & 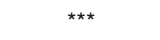 \\
\hline $\mathrm{CP}$ & Pirongia+Hamilton $^{d}$ & 219 & 2012,2013 & $y=0.64 \times C P+437$ & 0.73 & 611 & 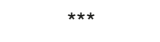 \\
\hline RPM & Hamilton & 135 & 2013 & $y=92 \times R P M+224$ & 0.79 & 546 & $* * *$ \\
\hline RPM & Pirongia & 109 & 2012 & $y=87 \times R P M+97$ & 0.63 & 774 & 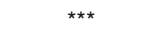 \\
\hline RPM & Pirongia+Hamilton $^{d}$ & 244 & 2012,2013 & $y=86 \times R P M+235$ & 0.73 & 664 & $* * *$ \\
\hline $\mathrm{SH}$ & Hamilton & 134 & 2013 & $y=94 \times S H-190$ & 0.81 & 520 & 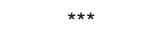 \\
\hline \multicolumn{8}{|l|}{ Plantain } \\
\hline $\mathrm{CP}$ & Hamilton & 132 & 2013 & $y=0.90 \times C P+535$ & 0.59 & 809 & 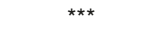 \\
\hline RPM & Hamilton & 135 & 2013 & $y=94 \times R P M+455$ & 0.70 & 711 & $\star \star * *$ \\
\hline $\mathrm{SH}$ & Hamilton & 135 & 2013 & $y=139 \times S H-175$ & 0.68 & 734 & $\star * \star$ \\
\hline \multicolumn{8}{|c|}{ Ryegrass-based pasture } \\
\hline $\mathrm{CP}$ & Hamilton & 125 & 2013 & $y=0.72 \times C P+1393$ & 0.43 & 1132 & 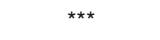 \\
\hline RPM & Hamilton & 135 & 2013 & $y=218 \times R P M+48$ & 0.73 & 772 & 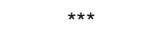 \\
\hline $\mathrm{SH}$ & Hamilton & 135 & 2013 & $y=148 \times S H+792$ & 0.51 & 1042 & 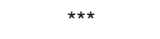 \\
\hline
\end{tabular}

a RPM, rising plate meter; CP, capacitance probe; $\mathrm{SH}$, uncompressed sward height.

${ }^{b}$ Where $\mathrm{CP}=$ calculated value from the capacitance probe (pre-cut corrected meter reading minus post-cut corrected meter reading); RPM = RPM reading in half $\mathrm{cm} ; \mathrm{SH}=$ uncompressed sward height in $\mathrm{cm}$.

$c \star \star \star, P<0.001$.

d The combined dataset from both sites was used to create the regression equations depicted in Figure 1. 

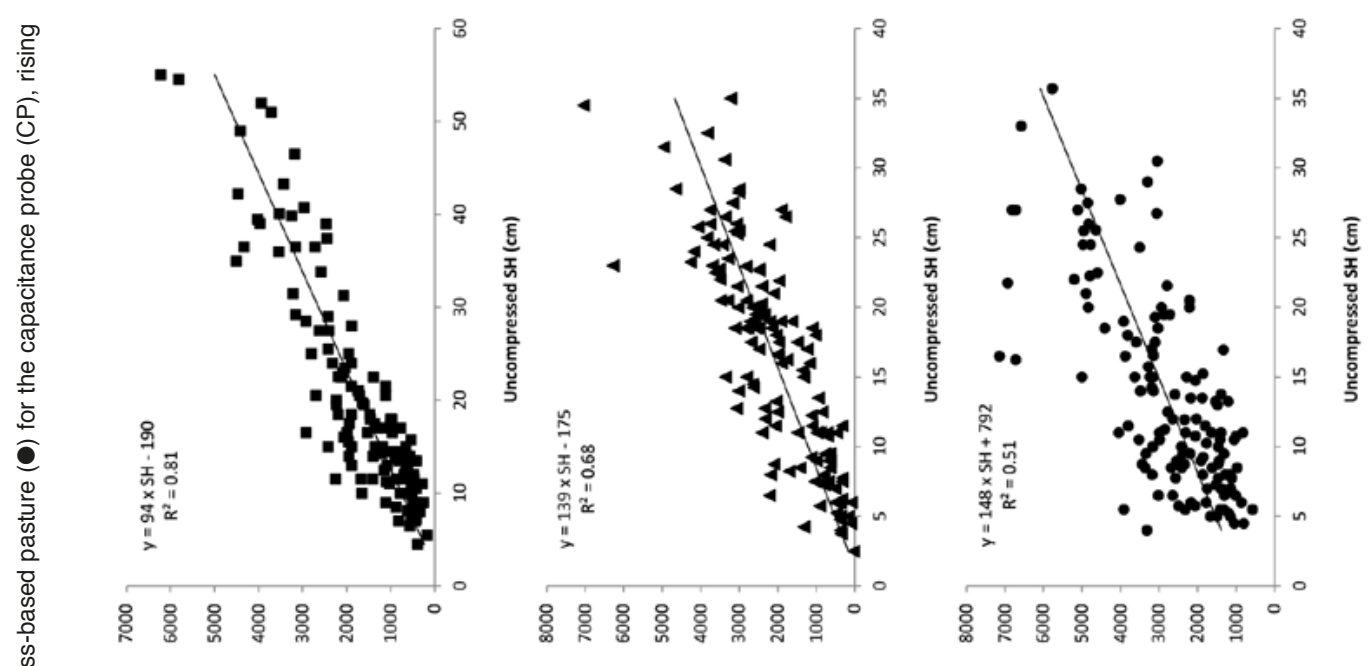

(eч/Wo 3y) ssew sรequว

(ey/Wa 3y) ssew эsеqroн

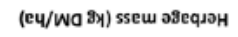
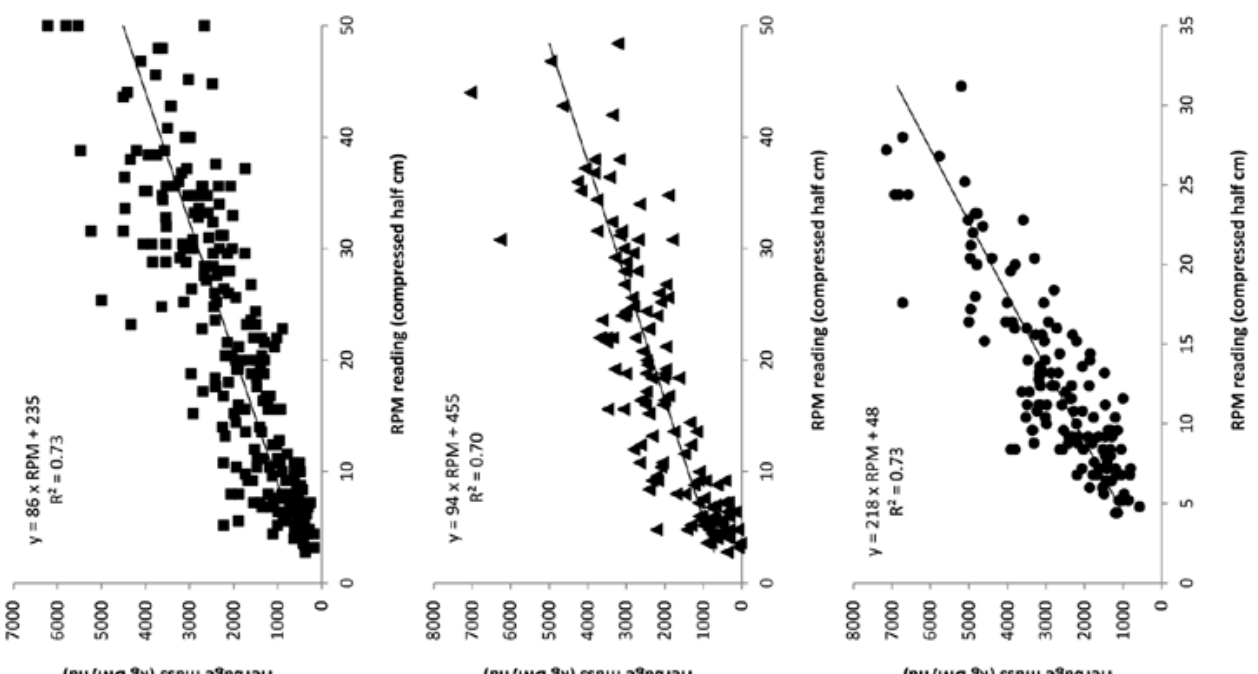

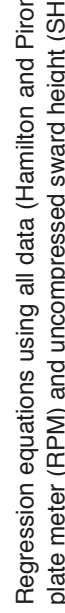

(еч/Wo 3y) ssew ә8еquaн

(eY/Wo 3y) ssew ә马еquән

(еч/Wo 8x) ssew ә8еqдан
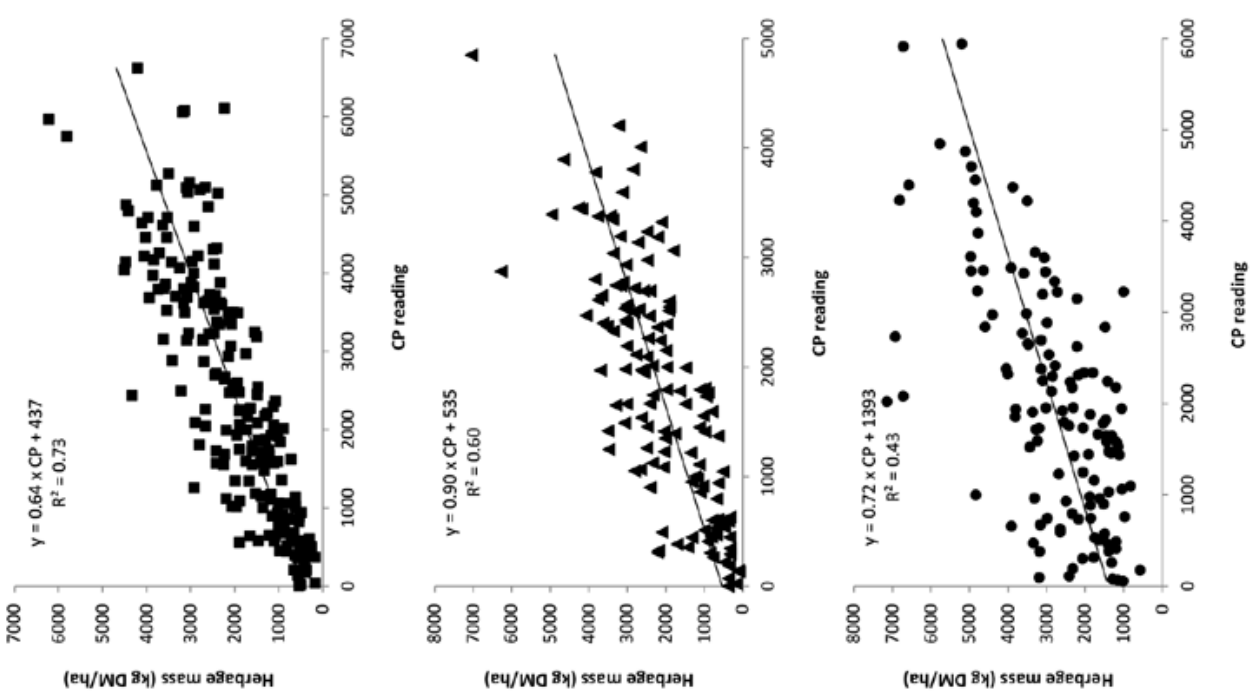
Another notable difference between the chicory equations from the two datasets was that the slope of the linear equation generated from the Pirongia sward was shallower than the experimental sward in Hamilton for both the RPM and CP. This could be due to a difference in plant dry matter percentage (DM\%) and/or change in plant morphology brought about through different climate conditions (i.e., soil moisture content and ambient temperature). Previous research (Litherland et al. 2008) indicated the use of plant DM\% in regression equations on sheep and beef grazed pastures significantly improved the estimate of change in herbage mass with both a CP and RPM. In the case of this study, substantially different rainfall was observed between the two datasets, with $389 \mathrm{~mm}$ recorded in 2012 in Pirongia and only $51 \mathrm{~mm}$ (plus 50 $\mathrm{mm}$ of irrigation) in 2013 in Hamilton. Furthermore, chicory plant dry weight can increase exponentially with thermal time $\left({ }^{\circ} \mathrm{C}\right.$.day) (Powell et al. 2007) and the average temperature during this study was $16.1^{\circ} \mathrm{C}$ and $19.0^{\circ} \mathrm{C}$ for the three months of 2012 and 2013 , respectively. Thus heightened DM growth for 2013 vs 2012 was likely, supporting the steeper slope of the 2013 regression equation. Both rainfalls and temperatures are fairly extreme, and may have affected the plant DM\%, altering the rate at which DM yield increased with plant height and volume.

In the experimental chicory sward, the uncompressed $\mathrm{SH}$ method produced an $\mathrm{R}^{2}$ of 0.81 , indicating that it may be an acceptable method of yield estimation. One potential problem with using height to estimate mass, however, is that it fails to take into account the density of the sward (Fulkerson \& Donaghy 2001). Therefore, chicory swards of varying density could vary in biomass and yet have a similar height. In a range of sward conditions uncompressed SH may, therefore, be less accurate than either the RPM or CP. Or it may simply be that more than two SH measurements are required to better account for the variability within the swards; this requires further investigation. The coefficient of variation for the SH method, which does not take into account plant density, was higher than the RPM, which does take into account density in its measurements.

In the plantain sward none of the tested methods had an $\mathrm{R}^{2}$ greater than 0.73 ; however, the RPM with an $\mathrm{R}^{2}$ of 0.70 could be considered acceptable, given the $\mathrm{R}^{2}$ in previous research has been below 0.70 (Table 1). This plantain sward had a plant density in mid April of 180 \pm 50 plants $/ \mathrm{m}^{2}$, again providing some indication of the swards in which the equation may be relevant.

The 2013 drought in the Waikato affected the size of the dataset and therefore the quality, as during data collection, it became difficult to gain readings from the $\mathrm{CP}$ on the dry soils and the minimal surrounding herbage mass. The $\mathrm{CP}$ is programmed to detect differences between the air and the ground (Serrano et al. 2011). When the difference did not meet the default threshold set internally by the manufacturer (when $\mathrm{CMR}<700$ ) no reading could be taken. Consequently, this reduced the size of the data set for the ryegrass-based pasture by 10 data points and influenced the accuracy of the linear regression. In a previous study (Neal \& Neal 1973), short dry pastures were also identified as a limitation to the CP. Under non-drought conditions, where pastures remain green, existing CPs can estimate herbage mass of ryegrass well (O'Donovan et al. 2002; Serrano et al. 2011; Stockdale \& Kelly 1984), with standard deviation (SD) ranging from 440 to 555 and $\mathrm{R}^{2}>0.75$ (Table 1). Since this experiment was undertaken, further commercial development of the $\mathrm{CP}$ has resolved the issue where the $\mathrm{CP}$ struggled to take measurements in dry conditions.

There was greater variability of yields at the higher end for all yield estimate methods of chicory and plantain (Figure 1). The majority of samples were taken at lower yields and the variability there was smaller than the higher yield end. An increased number of samples at the higher yield end would strengthen the regression equation, and should be a focus of future research. There was also large variation in yields at similar points of measure, perhaps due to the varying nature of plant density in the swards. This is one reason why a minimum number of measurements per paddock (e.g. 50) are recommended.

The equations developed in this study (Table 3) for chicory and plantain were created using swards from paddocks on two individual farms, for which they proved accurate; however additional data are required to ensure their relevance on swards in different environments where soils and climate can vary markedly. These equations allow farmers to better estimate herbage biomass. However, if postgrazing residuals on the chicory and plantain swards are consistently lower or higher than expected, it may be that the biomass is being over- or under-estimated. Therefore, the daily area should be increased when over-grazed or decreased when under-grazed. This is more likely to occur at greater herbage yields where there was often greater variability.

\section{Conclusion}

The RPM was a suitable tool for the estimation of biomass in pure chicory or plantain swards as it had similar accuracy to similarly developed calibration equations for ryegrass-based pasture. The $\mathrm{CP}$ and uncompressed $\mathrm{SH}$ methods also estimated chicory biomass with similar accuracy to the RPM.

Farmers, at least in the Waikato, can estimate first 
year chicory or plantain biomass through the summer and autumn period using the following equations:

Chicory biomass $(\mathrm{kg} \mathrm{DM} / \mathrm{ha})=86 \times \mathrm{RPM}$ reading + 235 , or $=0.64 \times \mathrm{CP}$ reading +437 , or $=94 \times \mathrm{SH}-$ 190.

Plantain biomass $(\mathrm{kg} \mathrm{DM} / \mathrm{ha})=94 \times \mathrm{RPM}$ reading + 455.

Further investigation is required to ensure these equations are valid over a range of first year sward conditions in different environments.

\section{ACKNOWLEDGEMENTS}

Thanks to Curtis Blythe, Adam Benton, Lewis Wallace, Dale Beker, Megan Laansdale, Morgan Pourau, Mylene Delarue and Imogen Bryan for assistance with field work. Thanks to Novel Ways Ltd, Hamilton for the use of the Pasture Master II ${ }^{\mathrm{TM}}$ throughout the data collection of this research. This study was funded by New Zealand dairy farmers through DairyNZ Inc. in partnership with Ministry of Primary Industries Primary Growth Partnership funding.

\section{REFERENCE}

Clark, D.A.; Anderson, C.B.; Berquist, T. 1990. Growthrates of 'Grasslands Puna' chicory (Chicorium intybus L.) at various cutting intervals and heights and rates of nitrogen. New Zealand Journal of Agricultural Research 33: 213-217.

Clark, D.A.; Litherland, A.; Mata, G; Burling-Claridge, R. 2006. Pasture monitoring from space. Proceedings of the South Island Dairy Event 7: 108-112.

Currie, P.O.; Morris, M.J.; Neal, D.L. 1973. Uses and capabilities of electronic capacitance instruments for estimating standing herbage. Grass and Forage Science 28: 155-160.

Fulkerson, W.J.; Donaghy, D.J. 2001. Plant-soluble carbohydrate reserves and senescence - key criteria for developing an effective grazing management system for ryegrass-based pastures: a review. Animal Production Science 41: 261-275.

Glassey, C.B.; Clark, C.E.F.; Roach, C.G.; Lee, J.M. 2013. Herbicide application and direct drilling improves establishment and yield of chicory and plantain. Grass and Forage Science 68: 178-185.

Jones, R.J.; Haydock, K.P. 1970. Yield estimation of tropical and temperate pasture species using an electronic capacitance meter. The Journal of Agricultural Science 75: 27-36.

L'Huillier, P.J.; Thomson, N.A. 1988. Estimation of herbage mass in ryegrass/white clover dairy pastures. Proceedings of the New Zealand Grassland Association 49: 117-122.

Litherland, A.J.; Webby, R.; Fraser, T.J.; Matthew, C.; McCleod, K.; Walcroft, J.; Bryant, J.; Devantier,
B.; Hoogendoorn, C.J.; Moss, R.; Clarke-Hill, W.J.; Schreurs, P.J. 2008. Indirect measurement of pasture mass and pasture growth rate on sheep and beef pastures. Proceedings of the New Zealand Grassland Association 70: 137-144.

Macdonald, K.A.; Penno, J.W. 1998. Management decision rules to optimise milk solids production on dairy farms. Proceedings of the New Zealand Society of Animal Production 58: 132-135.

Minneé, E.M.K.; Clark, C.E.F.; Clark, D.A. 2013. Herbage production from five grazable forages. Proceedings of the New Zealand Grassland Association 75: 245-250.

Neal, D.L.; Neal, J.L. 1973. Uses and capabilities of electronic capacitance instruments for estimating standing herbage. Grass and Forage Science 28: 8190.

Nobilly, F.; Bryant, R.H.; McKenzie, B.A.; Edwards, G.R. 2013. Productivity of rotationally grazed simple and diverse pasture mixtures under irrigation in Canterbury. Proceedings of the New Zealand Grassland Association, 75: 165-172.

O’Donovan, M.; Dillon, P.; Rath, M.; Stakelum, G. 2002. A comparison of four methods of herbage mass estimation. Irish Journal of Agricultural and Food Research 41: 17-27.

Piggot, G.J. 1986. Methods for estimating pasture drymatter on dairy farms in Northland. Proceedings of the New Zealand Grassland Association 47: 243247.

Powell, A.M.; Kemp, P.D.; Jaya, IK.D.; Osborne, M.A. 2007. Establishment, growth and development of plantain and chicory under grazing. Proceedings of the New Zealand Grassland Association 69: 41-45.

Roche, J.R. 2007. Milk production responses to preand postcalving dry matter intake in grazing dairy cows. Livestock Science 110: 12-24.

Roche, J.R.; Kay, J.K.; Phyn, C.V.C.; Meier, S.; Lee, J.M.; Burke, C.R. 2010. Dietary structural to nonfiber carbohydrate concentration during the transition period in grazing dairy cows. Journal of Dairy Science 93: 3671-3683.

Roche, J. R.; Kolver, E.S.; Kay, J.K. 2005. Influence of precalving feed allowance on periparturient metabolic and hormonal responses and milk production in grazing dairy cows. Journal of Dairy Science 88: 677-689.

Rollo, M.; Sheath, G.; Slay, M.; Knight, T.; Judd, T.; Thomson, N. 1998. Tall fescue and chicory for increased summer forage production. Proceedings of the New Zealand Grassland Association 60: 249254.

Rumball, W. 1986. Grasslands Puna Chicory (Chichorium intybus L.). New Zealand Journal of Experimental Agriculture 14: 105-107. 
Serrano, J.; Peça, J.; Marques da Silva, J.; Shahidian. S. 2011. Calibration of a capacitance probe for measurement and mapping of dry matter yield in Mediterranean pastures. Precision Agriculture 12: 860-875.

Stewart, A.V. 1996. Plantain (Plantago lanceolata) a potential pasture species. Proceedings of the New Zealand Grassland Association 58: 77-86.
Stockdale, C.R.; Kelly, K.B. 1984. A comparison of a rising-plate meter and an electronic capacitance meter for estimating the yield of pastures grazed by dairy-cows. Grass and Forage Science 39: 391-394. 